\title{
A Note on the Gordon Growth Model with Earnings per Share
}

\author{
Olga S. Belomyttseva \\ Department of Finance and Accounting \\ National Research Tomsk State University \\ Tomsk, Russian Federation \\ olbel@f123.ru
}

\author{
Larisa S. Grinkevich \\ Department of World Economy and Taxation \\ National Research Tomsk State University \\ Tomsk, Russian Federation \\ nasty_saturn@mail.ru
}

\begin{abstract}
The paper analyzes the Gordon growth model and outlines advantages and disadvantages of the model. The authors present their justification of the Gordon growth model, different from Gordon's approach, by introducing the earnings per share indicator. The authors substantiate need for maximization of dividend payments under specified conditions.
\end{abstract}

Keywords-Gordon growth model; dividend discount model; earnings per share

\section{INTRODUCTION}

Dividend policy is one of the most complex and controversial aspects of financial studies. F. Black supported a similar view when stated that dividend picture "seems like a puzzle, with pieces that do not fit together" [1]. R. Brealey, S. Myers and F. Allen described dividend policy as one of the top ten unsolved problems in finance [2]. Accordingly, valuation of stock on the basis of dividend payments has been attracting substantial interest for nearly 60 years.

The Gordon growth model (GGM) was proposed by Gordon in 1962, as opposed to dividend irrelevance theory, and is now considered the most commonly used fundamental valuation techniques in practice.

It should be noted that many studies rather often refer to this model as the Dividend discount model (DDM). Various authors use both DDM and GGM, implying the same classical formula. A number of authors [3] noted that these models are analogues. We agree with this statement. Apparently, the terminology discrepancy occurred because both the GGM and DDM are based on dividend discount. For the purpose of this paper we will use the acronym GGM and thus emphasize Myron Gordon's personal contribution to the theory.

Undoubtedly, the GGM has a number of limitations. However, it remains relevant for economics in terms of its possible applications, as well as its use under specific limitations. Studies to modify the GGM were conducted by Brennan [4], Farrell [5], Barsky and De Long [6], Hurley and Johnson [7-9], Yao [10], Hurley and Fabozzi [11], Pages [12], Gorman [13], Foerster and Sapp [14], Heinrichs, Hess, Homburg, Lorenz, and Sievers [15]. The notable economists currently involved in the investigation of the GGM are Acheampong and Agalega [16], Hurley [17], Irons [18], Lazzati and Menichini [19], Majanga [20].

Brennan [4] conducted a comparative analysis of the GGM with the Modigliani-Miller theorem, claiming that the Gordon argument rests upon a confounding of the effects of dividend policy and investment policy. Given that, Brennan argued that the dividend irrelevance theorem by Modigliani and Miller could be derived from a somewhat weaker assumption than that of symmetric market rationality.

Farrell [5] modified the GGM to estimate stock's duration

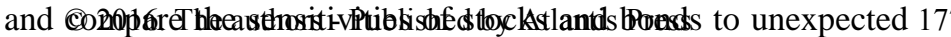

changes in inflation rates.

Barsky and De Long [6] argued that a small random walk component in the growth rate of dividends, when extrapolated into the future, is capable of reproducing the large swings in US stock prices over the period 1880-1990.

Hurley and Johnson [7-9] introduced a series of dividend models consistent with uncertainty of dividends.

Yao [10] proposed a trinomial dividend valuation model. A good general summary of dividend models in multiple variations is done by Hurley and Fabozzi [11].

Pages investigated whether the assumption of a "permanent" growth rate of dividends is consistent with a constant discount rate [12].

Gorman [13] extended the one-stage the GGM into a multistage environment.

Foerster and Sapp [14] found that dividend based models perform well at explaining actual prices; they perform better than commonly used earnings based models. Their study used information on the share price, dividend payments and earnings for a single firm over a period of more than 120 years.

Heinrichs, Hess, Homburg, Lorenz, and Sievers [15] extended the most important company valuation methods by correcting for dirty surplus accounting and employing consistent terminal value calculations, including comprehensive dividend definitions.

Acheampong and Agalega [16] discovered that there are indeed differences in the actual price series and predicted price series based on estimates using the GGM for selected stock on the Ghana Stock Exchange.

Hurley [17] presented two generalized stochastic models: one with geometric dividend growth; the other assumes it is additive.

Irons [18] proposed a new method, tied to the company's life cycle and dividend policy, which allows for these periods of extraordinary growth within the original GGM. This was illustrated by comparing the intrinsic value calculated with the enhanced GGM to that using the nonconstant growth method.

Lazzati and A.A. Menichini [19] derived a dynamic model of the firm using real options and the assumption of secular growth within the framework of the GGM. They identified industries where valuation models can lead to considerable underpricing of securities.

Majanga [20] revealed that there is a significant positive relationship between dividends and stock price as touted by the dividend valuation models of determining stock. His study was conducted based on the data sets of thirteen local companies listed on the Malawi Stock Exchange for the period 2008 to 
2014.

Hence, the objective of this study is to substantiate the GGM based on Earnings per Share (EPS) indicator.

The structure of the paper is as follows. Section 2 presents the GGM analyzes. The GGM justification using EPS is introduced in Section 3. The results and prospects for further investigation are outlined in Section 4.

\section{DISCUSSING THE GGM}

In this model, the value of the firm's equity can be represented as a growing perpetuity based on next period's expected dividend [21].

The Gordon Model is directly contrary to the dividend irrelevance theory by Miller and Modigliani presented earlier in 1958 , stating that once the investment policy of a firm is given, the price of its shares is invariant with respect of the amount of the dividends paid.

According to Gordon [21], the price of a share is equal to the discounted value of expected future dividends. Dividends are expected to grow at the constant rate $\mathrm{g}$, the discount rate (required rate of return) is $\mathrm{k}$. This principle leads to the familiar valuation equation (classical representation of the model) (1).

$$
P=\frac{D_{1}}{(k-g)} \text { where } g<k
$$

$\mathrm{P}$ is the current share price; $\mathrm{D}_{1}$ is the next dividend per share the firm will pay.

Equation (1) is simplified. The original format implies direct discounting of the future dividend payments (2).

$$
P=\sum_{t=1}^{\infty} D \frac{(1+g)^{t}}{(1+k)^{t}} \quad \text { where } g<k
$$

Here D is the current dividend.

There are two basic assumptions underlying the GGM, i.e. the required return on the firm's common share and the dividend growth rate are constantly moving forward.

Besides, there are other assumptions that are partly subsequent from the above-mentioned ones. These are stable business and financial leverage, steady growth and paying all firms free cash flow as dividends to equity holders. The GGM is generally derived under ideal conditions such as clean surplus accounting and full payoff information (share repurchases and capital contributions).

The GGM demonstrates that increasing dividends directly increase the share price. Thus, the market price of the shares is directly dependent on the dividend policy of a company.

The GGM has both advantages and disadvantages. In our view, the most significant advantages include the following:

- This model is very popular in practice because the estimation of the future growth rate of dividends required by the GGM is less stringent than the estimation of all future dividend payments.

- The fact that the GGM attempts to calculate shares' value based on the predicted sums to be paid out to investors. In theory, this should provide a very solid ground to calculate the share's true value in current conditions.

- The model can be highly useful over the short to medium term, putting to use widely available company research over timescales of up to five years.
- The GGM can still be valuable in stable industries over the longer term if investors are willing to assume that current dividend payout policies will remain in place.

- The model should be used primarily for the valuation of the untraded shares. However, its application is feasible in traded shares in order to find undervalued securities.

The disadvantages of the model are as follows:

- The standard GGM is of no value in determining the estimated value of companies that do not pay dividends. This typically presents no problems in mature industries, but the models generally appear less effective in new and innovative companies, where investors commonly expect share price appreciation rather than high dividend payments.

- Accurate forecasting of a company's ability to maintain a certain rate of dividend growth over the longer term can be extremely difficult. The GGM rely heavily on the validity of the factual data, which questions their value due to the challenges associated with accurately forecasting growth rates beyond five or so years.

- When used for longer-term analysis, the valuations provided by dividend discount models leave out a probability of a deliberate change to a company's dividend policy. This can further compromise the usefulness of the GGM over the longer term.

- The model assumes perfect markets and takes no account of the profit taxes.

Though widely used, the GGM is subject to criticism for its assumptions, especially assumption of geometric growth.

Gordon is traditionally considered Lintner's collaborator in the development of so-called bird in hand theory. Gordon [21] claims that investors prefer dividends because their receipt represents guaranteed cash. These cash receipts are more available as they are not affected by uncertainty and future risks.

Lintner [22] studied dividend policies of several US corporations in the postwar years and found that companies prefer to maintain dividends. According to Lintner [22], managers try to smooth dividends over time avoiding making changes. Lintner [22] also stresses that dividend policy is a major decision made by firm management.

An interest in the GGM from researchers and practitioners indicates its high relevance, but there are also staunch supporters of the theory by Miller and Modigliani. They refer to Gordon's model as a "popular sentiment of the times" [23].

\section{PROVING THE GGM USING EPS}

The authors of this paper distance from Gordon's approach and attempt to justify GGM using the EPS indicator. EPS is the portion of a company's profit allocated to each traded common share. It serves as an indicator of a company's profitability and is a classic indicator, which is important and relied upon by investment analysts to measure performance of business entities. EPS can be used to measure the financial health and prospects of a company either in the short or long term [24].

Let $\mathrm{P}_{0}$ be the initial value of a common share. Then, we have the following equation with the notations indicated above:

$$
E P S_{1}=P_{0} * k
$$

EPS $_{1}$ here stands for the earnings of the next year.

We introduce DPR (dividend payout ratio), calculated as the percentage of earnings paid to shareholders in dividends. DPR, 178 according to other limitations made by Gordon is considered 
constant. Thus, the next dividend per share, the company will pay, will equal:

$$
D_{1}=E P S_{1} * D P R=P_{0} * k *(1-D P R)
$$
$\Delta \mathrm{P}_{1}$ :

The share price change in the first year will be calculated as

$$
\Delta P_{1}=E P S_{1}-D_{1}=P_{0} * k *(1-D P R)
$$

In (5) $\Delta P_{1}$ is part of profit that is reinvested.

Hence, we have

$$
E P S_{1}=\Delta P_{1}+D_{1}
$$

The share price within a year $\left(\mathrm{P}_{1}\right)$ can be calculated by means of the following equation:

$$
P_{1}=P_{0}+\Delta P_{1}=P_{0} *(1+k *(1-D P R))
$$

Since $\mathrm{k}$ and DPR are constants, we obtain the following $\mathrm{EPS}_{2}$ in 2 years:

$$
E P S_{2}=P_{1} * k=P_{0} * k *(1+k *(1-D P R))
$$

By modifying (8), we get the following result:

$$
E P S_{2}=E P S_{1} *(1+g)
$$

Now, we determine the dividend growth rate $g$ with (10).

$$
g=k *(1-D P R)=k-k * D P R
$$

Subsequently, we obtain:

$$
k-g=k * D P R
$$

and

$$
g<k
$$

Dividends for the second year can be calculated as follows:

$$
D_{2}=P_{1} * k * D P R=D_{1} *(1+g)
$$

The share price change in the second period will be $\Delta \mathrm{P}_{2}$, which is estimated with (14).

$$
\Delta P_{2}=E P S_{2}-D_{2}=E P S_{1} *(1+g) *(1-D P R)
$$

Hence, the share price in two years $\left(\mathrm{P}_{2}\right)$ can be determined using the following equation:

$$
P_{2}=P_{1}+\Delta P_{2}=P_{1} *(1+k *(1-D P R))
$$

By modifying (14), we obtain:

$$
P_{2}=P_{0} *(1+g)^{2}
$$
(17)

The year-end dividend $(n+1)\left(D_{n+1}\right)$ will be calculated with

$$
D_{(n+1)}=D_{n} *(1+g)
$$

For the purpose of determining the share price, we will use the classical DDM equation (18).

$$
P=\frac{D_{1}}{\left(1+k_{1}\right)}+\frac{D_{2}}{\left(1+k_{2}\right)^{2}}+. . \frac{D_{t}}{\left(1+k_{t}\right)^{t}}+. .
$$

By substituting the obtained values of D in (18) (herein, $\mathrm{k}$ remains constant), we get

$$
\frac{P_{0} * k * D P R}{1+k}+\frac{P_{0} * k * D P R *(1+g)}{(1+k)^{2}}+\ldots
$$

When (19) is modified, the result can be displayed as (20).

$$
\frac{P_{0} * k * D P R}{k-g}=\frac{D_{1}}{k-g}=P_{0}
$$

Thus, the GGM has been proven again.

Now, in order to formulate specific conclusions we slightly modify the equations and determine $\mathrm{P}_{0}(21)$, DPR (22) and once again $\mathrm{P}_{0}(23)$ based on the EPS (22).

$$
\begin{gathered}
P_{0}=\frac{E P S_{1} * D P R}{k-g} \\
D P R=\frac{(k-g)}{k}=1-\frac{g}{k} \\
P_{0}=\frac{E P S_{1} *(k-g)}{k *(k-g)}=\frac{E P S_{1}}{k}
\end{gathered}
$$

It is also important to note that when DPR equals 1 (100\% of the net profit allocated for dividend payment) based on equation (21) we have the highest share price. If DPR equals 0 (no dividends), then the share price equals zero.

Regarding, the EPS indicator, it should be emphasized that there is a direct correlation between its change and the share price (23).

In other words, the GGM clearly demonstrates need for maximizing the payout.

\section{CONCLUSION}

One of the most important decisions in corporate finance is whether to distribute profit to shareholders as dividends or reinvest it to open up new opportunities, Should it be distributed, the amount of profit to be allocated to a shareholder and the amount to be returned to the business remains a challenging question. When addressing this, managers must consider the impact of the adopted dividend policy on the maximization of shareholder's wealth and, most importantly, the impact on the company's share price.

We agree with Acheampong and Agalega's statement that "No method for stock valuation can be said to be either right or wrong" [16]. However, the GGM is frequently used and studied, which indicates its high relevance and importance.

Foerster and Sapp [14] confirm that dividend models are considered the most popular and relevant models that explain the share prices. According to Yao [10], the GGM is universally 179 recommended in textbooks for students and analytical 
departments of investment companies and banks. The situation remains unchanged today.

Using EPS indicator, we derived the GGM formula (20) that fully complies with its classic representation (1). Our findings also revealed that the EPS has a direct impact on the common share price.

Seetharaman and Raj [24] and Attah-Botchwey [25] used factual data in their investigations and came to similar conclusions regarding the direct relationship between EPS or dividend payments and share prices. Seetharaman and Raj [24] analyzed the relationship of EPS and share prices in Public Bank Berhad (Malaysia). Attah-Botchwey [25] conducted a study to reveal the impact of dividend payment and its relationship with share prices in some companies listed on the Ghana Stock Exchange. His findings suggest that higher dividend payments lead to growing share prices due to higher demand on shares, while firms with lower dividends demonstrate declining share prices, all other conditions being equal.

Further investigations are required to examine different modifications of GGM and their implementation for share valuation of Russian joint-stock companies and discover the relationship between their EPS indicators and share prices.

\section{REFERENCES}

[1] F. Black, "The dividend puzzle", J. Portfolio Manage., 1976, vol. 2, no. 2, pp. $5-8$.

[2] R. Brealey, S. Myers, and F. Allen, Principles of Corporate Finance. Maidenhead, Berkshire: McGraw-Hill, 2010.

[3] R.S. Harris, K.M. Eades, and S.J. Chaplinsky. "The dividend discount model", Darden case no. UVA-F-1234. Darden Business School, University of Virginia, 1998, Retrieved February 26, 2016, from http://papers.ssrn.com.

[4] M. Brennan, "A note on dividend irrelevance and the Gordon valuation model”, J. Financ., 1971, vol. 26, no. 5, pp. 1115-1122.

[5] J.L. Farrell, "The dividend discount model: a primer", Financ. Anal. J., 1985, vol. 41, no. 6, pp. 16-19+22-25.

[6] R.B. Barsky and J.B. De Long, "Why Does the Stock Market Fluctuate?", Q. J. Econ., 1993, vol. CVIII, pp. 291-311.

[7] W.J. Hurley and L.D. Johnson, "A realistic dividend valuation model", Financ. Anal. J., 1994, vol. 50, no. 4, pp. 50-54.

[8] W.J. Hurley and L.D. Johnson, "Stochastic two-phase dividend discount models", J. Portfolio Manage., 1997, vol. 23, no. 4, pp. 91-98.
[9] W.J. Hurley and L.D. Johnson, "Generalized Markov dividend discount models", J. Portfolio Manage., 1998, vol. 25, no. 1, pp. 27-31.

[10] Y.L. Yao, "A trinomial dividend valuation model", J. Portfolio Manage., 1997, vol. 23, no. 4, pp. 99-103.

[11] W.J. Hurley and F. Fabozzi, "Dividend discount models", in Selected Topics in Equity Portfolio Management, F.J. Fabozzi, Ed. New Hope, Pennsylvania, 1998.

[12] H. Pages, "A note on the Gordon growth model with nonstationary dividend growth", BIS Work. Papers, 1999, no. 75, Retrieved February 26, 2016, from http://papers.ssrn.com.

[13] L. Gorman, "An internally consistent approach to common stock valuation", Int. Bus. Econ. Res. J., 2002, vol. 1, no. 3, pp. 69-78.

[14] S.R. Foerster and S.G. Sapp, "The dividend discount model in the long-run: a clinical study", J. Appl. Financ., 2005, vol. 15 (2), fall/winter, pp. 1-21.

[15] N. Heinrichs, D. Hess, C. Homburg, M. Lorenz, and S. Sievers, "Extended dividend, cash flow and residual income valuation models - accounting for deviations from ideal conditions", Contemp. Account. Res., 2013, vol. 30, no. 1, pp. $42-79$.

[16] P. Acheampong, E. Agalega, "Examining the dividend growth model for stock valuation: evidence from selected stock on the Ghana Stock Exchange”, Res. J. Financ. Account., 2013, vol. 4, no. 8, pp. 112-121.

[17] W.J. Hurley, "Calculating first moments and confidence intervals for generalized stochastic dividend discount models", J. Math. Financ., 2013, vol. 3, pp. 275-279.

[18] R. Irons, "Enhancing the dividend discount model to account for accelerated share price growth", J. Account. Financ., 2014, vol. 14 (4), pp. 153-159.

[19] N. Lazzati and A.A. Menichini, "A dynamic approach to the dividend discount model", June 10, 2014, Retrieved March 12, 2016, from http://papers.ssrn.com.

[20] B.B. Majanga, "The dividend effect on stock price-an empirical analysis of Malawi listed companies", Account. Financ. Res., 2015, vol. 4, no. 3, pp. 99-105.

[21] M. Gordon, The Investment, Financing, and Valuation of the Corporation. Homewood, III: Irwin, 1962.

[22] J. Lintner, "Distribution of incomes of corporations among dividends, retained earnings, and taxes", Am. Econ. Rev., 1956, vol. 46, no. 2, pp. 97 113.

[23] H.K. Baker, "Dividends and dividend policy: an overview", in Dividends and Dividend Policy, H.K. Baker and R.W. Kolb, Eds. Hoboken. NJ: Wiley, 2009.

[24] A. Seetharaman and J.R. Raj, "An empirical study on the impact of earnings per share on stock prices of a listed bank in Malaysia", Int. J. Appl. Econ. Financ., 2011, vol. 5, no.2, pp. 114-126.

[25] E. Attah-Botchwey, "The impact of dividend payment on share price of some selected listed companies on the Ghana Stock Exchange", Int. J. Human. Soc. Sci., 2014, vol. 4, no. 9, pp. 179-190. 